Jpn. J. Limnol., 49, 2, 109-117, 1988.

\title{
Composition and Abundance of Zoobenthos in the Profundal Zone of Lake Oze-numa in Central Japan
}

\author{
Akifumi Ohtaka, Atsuo Ujirye, and Shunsuke F. Mawatari
}

\begin{abstract}
Composition and abundance of zoobenthos in the profundal zone of Lake Oze-numa $\left(36^{\circ} 56^{\prime} \mathrm{N}\right.$, $\left.139^{\circ} 18^{\prime} \mathrm{E}\right)$ were studied at two sites, Lake Center and Off Nushiri, from May to September 1986. Among the eight taxa recorded, three species (Tubifex sp., Limnodrilus hoffmeisteri, and Chironomus sp.) accounted for more than $95.5 \%$ of the macrobenthos in number. Species diversity, density, and biomass of macrobenthos were lower at Lake Center ( $8.8 \mathrm{~m}$ deep in average) than those of Off Nushiri $(6.8 \mathrm{~m})$. Oxygen content was probably an important factor in these differences between the sites. At Off Nushiri, Tubifex sp. and L. hoffmeisteri reproduced throughout the study period but with low proportions ; pupae of Chironomus sp. were found only in late June.
\end{abstract}

Key words : Lake Oze-numa, zoobenthos, profundal zone, faunal composition.

\section{Introduction}

It has been recognized that Oze district including Lake Oze-numa is of a great importance in earth and biological sciences because it provides a unique situation which enables us to study the complicated origin and history of topography, flora and fauna in central Japan (HARА, 1982). Consequently, many biological researches have been made on Lake Ozenuma. However, previous studies on zoobenthos were mostly restricted in the littoral region (e.g KABl'RAKI, 1933 ; MIYADI, 1936 ; KURITA et al., 1975 ; G(onl et al., 1980 ; Kurita and Minenura, 1981). Although KuriTa et al. (1974) studied zoobenthos including those of the profundal zone, it is difficult to clarify the profundal characteristics from this work, since they presented the profundal data mixed up with the littoral ones.

To get a basic and accurate knowledge of the profundal zoobenthos in Lake Oze-numa, we undertook a periodic census from May to September 1986. As a second report of the survey, the present paper covers the composition and abundance of profundal zoobenthos in Lake Oze-numa during non-ice-covered period. This study is a part of the various scientific researches on Lake Oze-numa, which are conducted by Gunma Institute of Public Health and other institutes in Gunma Prefecture to describe the limnological features of the lake and to prevent artificial pollutions.

\section{Study sites and methods}

Lake Oze-numa $\left(36^{\circ} 56^{\prime} \mathrm{N}, 139^{\circ} 18^{\prime} \mathrm{E}\right)$ is an intermountain lake situated on the border of Gunma and Fukushima Prefectures in central Japan. Elevation of the water surface is $1,665 \mathrm{~m}$, the surface area is $1.6 \mathrm{~km}^{2}$ and the maximum depth is $9.5 \mathrm{~m}$ (HorIE, 1962). Ice and snow cover the entire lake during the winter period.

Two sampling sites, Off Nushiri and Lake Center

(Fig. 1),were selected and marked by buoys within the profundal zone of the lake. Off Nushiri was 6 . $8 \mathrm{~m}$ deep in average and the Lake Center, which is near the deepest point of the lake, had a depth of 8 . $8 \mathrm{~m}$. There was no vegetation around the sites. Samplings were made monthly from May to September 1986. At both sites, three (May) or five (other months) bottom samples were taken using a basic type of Ekman-Birge grab (base $225 \mathrm{~cm}^{2}$ ). The replicated bottom samples were immediately passed together through a screen with a mesh size of $0.245 \mathrm{~mm}$, and the remainder including animals was fixed with $10 \%$ formalin solution. Animals were sorted in the laboratory under a binocular microscope. The sorted animals were identified, counted and weighed by species; as for oligochaetes, mature worms distinguished by their clitellum were separately treated from immature ones. MacArthur's species diversity index ( $\mathrm{H}^{\prime}$ ) was calculated for macrobenthos. For determining the 


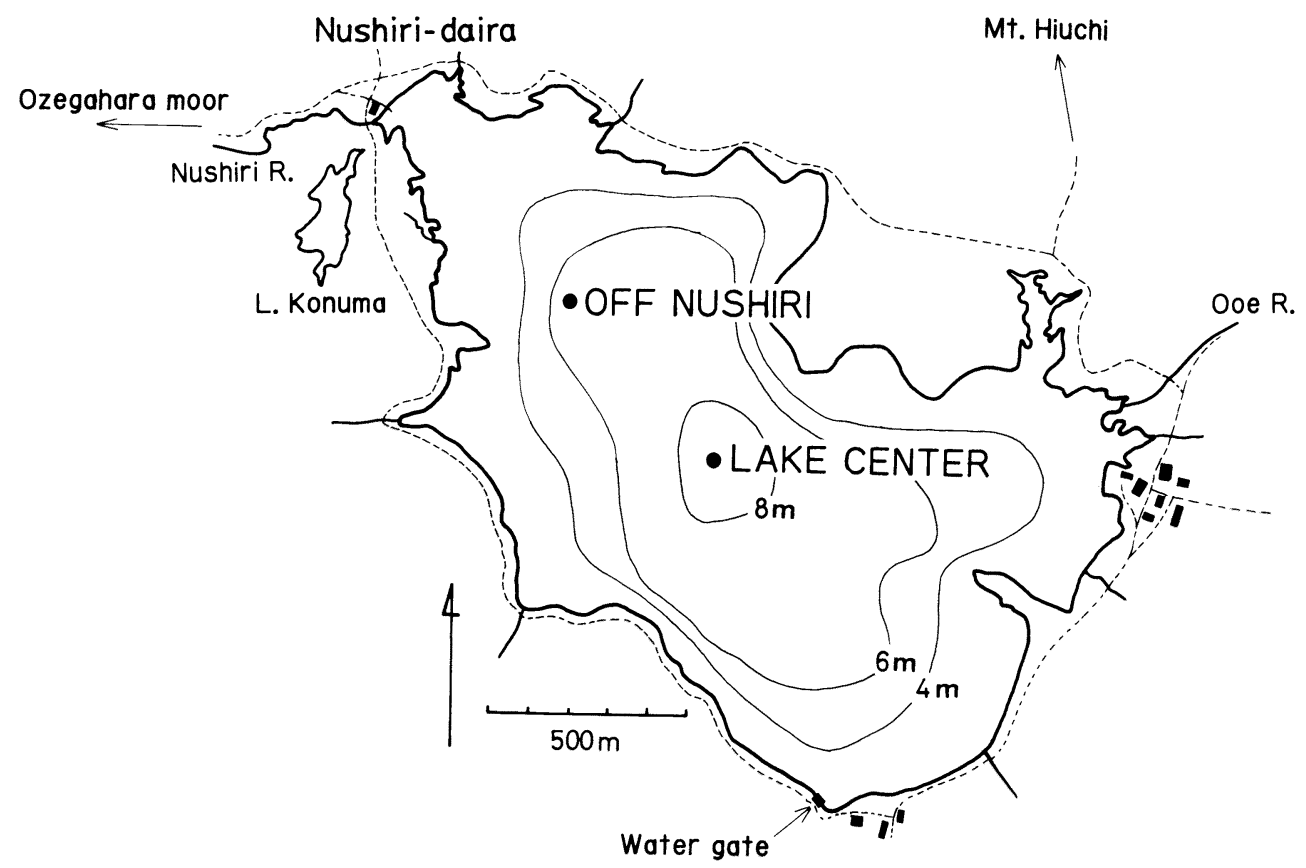

Fig. 1 Two study sites in Lake Oze-numa. Contour lines were drawn after Mr. Y. NAKAJIMA (pers. comm.).

developmental stage, the width at the eighth segment in oligochaetes (OHTAKA, 1985), or the body length and head breadth in chironomids were measured for specimens collected at Off Nushiri. The gut contents of the animals were examined under a microscope after their digestive tracts were dissected out. Meiofauna such as nematodes, ostracods, and harpacticoids were recorded but omitted from the quantitative result and discussion because of being so small that most of them were sieved out.

Dissolved oxygen was measured at the surface and $6 \mathrm{~m}$ depth at Lake Center. Water depth and temperatures of water and mud were measured at every sampling occasion and in 21 October 1986 by Dr. A. Sugawa (Gunma University).

\section{Results}

\section{3-1. Environmental factors}

Environmental conditions of the study sites are

Table 1. Environments of sampling sites, Off Nushiri and Lake Center (in parentheses). Water depth and temperature are after Dr. A. Sicrawa (unpubl.).

\begin{tabular}{|c|c|c|c|c|c|c|c|}
\hline & & $\begin{array}{l}29 \text { May } \\
1986\end{array}$ & 25 June & 23 July & $\begin{array}{c}26 \\
\text { August }\end{array}$ & $\begin{array}{c}24 \\
\text { September }\end{array}$ & $\begin{array}{c}21 \\
\text { October }\end{array}$ \\
\hline \multicolumn{2}{|l|}{ Water depth (m) } & $\begin{array}{l}7.1 \\
(9.0)\end{array}$ & $\begin{array}{c}6.6 \\
(8.5)\end{array}$ & $\begin{array}{l}7.1 \\
(9.1)\end{array}$ & $\begin{array}{c}6.5 \\
(8.6)\end{array}$ & $\begin{array}{l}6.8 \\
(8.8)\end{array}$ & $\begin{array}{c}6.7 \\
(8.9)\end{array}$ \\
\hline \multicolumn{2}{|c|}{$\begin{array}{l}\text { Secchi disk transparency } \\
\qquad(\mathrm{m})\end{array}$} & $\begin{array}{c}3.0 \\
(3.0)\end{array}$ & $\begin{array}{c}4.4 \\
(5.0)\end{array}$ & $\begin{array}{c}4.3 \\
(4.3)\end{array}$ & $\begin{array}{c}4.7 \\
(4.7)\end{array}$ & $\begin{array}{l}2.4 \\
(2.2)\end{array}$ & $\begin{array}{l}2.6 \\
(2.6)\end{array}$ \\
\hline \multicolumn{2}{|l|}{$\begin{array}{l}\text { Temperature of } \\
\text { water surface }\left({ }^{\circ} \mathrm{C}\right)\end{array}$} & $\begin{array}{l}10.0 \\
(9.5)\end{array}$ & $\begin{array}{c}16.0 \\
(16.0)\end{array}$ & $\begin{array}{c}17.5 \\
(17.3)\end{array}$ & $\begin{array}{c}22.6 \\
(22.7)\end{array}$ & $\begin{array}{c}17.2 \\
(17.5)\end{array}$ & $\begin{array}{l}9.3 \\
(9.1)\end{array}$ \\
\hline \multicolumn{2}{|l|}{$\begin{array}{l}\text { Temperature of } \\
\text { mud surface }\left({ }^{\circ} \mathrm{C}\right)\end{array}$} & $\begin{array}{c}6.2 \\
(6.4)\end{array}$ & $\begin{array}{l}10.0 \\
(8.3)\end{array}$ & $\begin{array}{l}11.8 \\
(9.9)\end{array}$ & $\begin{array}{l}15.6 \\
(12.5)\end{array}$ & $\begin{array}{c}16.1 \\
(13.8)\end{array}$ & $\begin{array}{c}9.5 \\
(8.9)\end{array}$ \\
\hline \multirow{2}{*}{$\begin{array}{l}\text { Dissolved oxygen } \\
\qquad\left(\mathrm{mg} \mathrm{1}^{-1}\right)\end{array}$} & surface & $(9.1)$ & $(8.7)$ & $(7.8)$ & $(7.6)$ & $(7.8)$ & $(9.1)$ \\
\hline & $6 \mathrm{~m}$ & $(8.9)$ & $(9.4)$ & $(7.1)$ & $(5.8)$ & $(7.5)$ & $(9.0)$ \\
\hline
\end{tabular}


shown in Table 1. The fluctuation of water depth is mainly due to artificial drainings through the southern water gate of the lake. Modified Carlson's trophic state index (AIZAKI, 1981) calculated from Secchi disk transparency ranged from 38 to 52 showing the lake water was mesotrophic as SAIJO and Sakaguchi (1954) previously. noted. Mud temperature became highest in September, and the difference between sites was less than about $3^{\circ} \mathrm{C}$. Oxygen concentration at Lake Center did not show any marked difference between the surface and the depth of $6 \mathrm{~m}$ even in summer. Although oxygen concentration of the bottom water was not measured in the present study, the bottom of Lake Center must have been more reductive than Off Nushiri, since the bottom samples of Lake Center were deep black, while those of Off Nushiri were blackish grey.

\section{3-2. Zoobenthos}

\section{3-2-1. Benthic fauna}

During the study period, the following taxa were collected :

Nematoda ; not determined.

Oligochaeta ; Tubifex sp., Limnodrilus hoffmeisteri Claparède.

Chironomidae ; Chironomus sp., procladius sp., Chironomidae gn. sp.

Ostracoda ; not determined.

Harpacticoida ; not determined.

All above forms were found at Off Nushiri, while Procladius sp., ostracods, and harpacticoids were not collected from Lake Center.

Tubifex sp. is left undetermined in the present paper because no detailed taxonomic examination was made, though it closely resembles Tubifex tubifex Müller. All the specimens of Limnodrilus hoffmeisteri examined had the penis sheaths of "typical" type (OHTAKA, 1985). Two forms of oligochaete cocoons were collected. They were identified with those of L. hoffmeisteri and Tubifex sp. by the setal characters of the young worms about to hatch out. As shown in Fig. 2 and Table

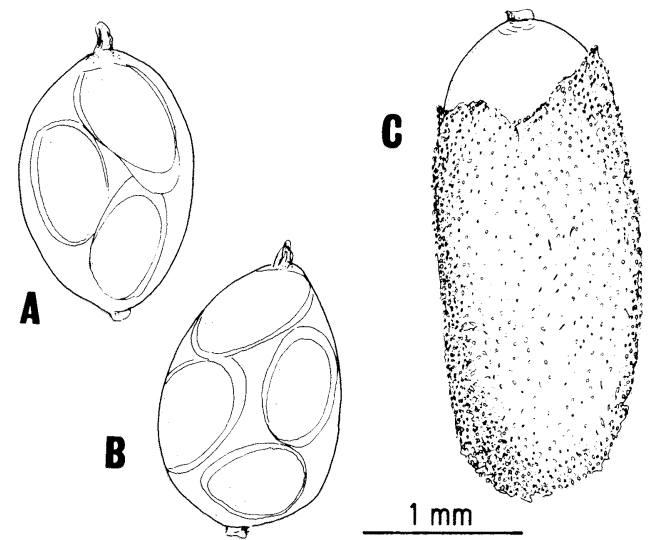

Fig. 2 Cocoons of Tubifex sp. (A, B) and Limnodrilus hoffmeisteri (C) collected from Off Nushiri, Lake Oze-numa in 23 July 1986.

2, cocoons of $L$. hoffmeisteri were cigar shaped, with a tight mud covering $0.1-0.2 \mathrm{~mm}$ thick, and larger than the naked and spindle or pear-shaped cocoons of Tubifex sp. The cocoon of L. hoffmeisteri collected well agreed in morphology with the previous description by ARKhIPOVA (1983).

The larva of Chironomus sp. belongs to the plumosus group (SASA,1978), and the pupa resembles $C$. nipponensis Tokunaga in its unique feature of caudolateral scales with 8 th abdominal segment which forked into two or more spurs. Accurate identification of this species could not be made because the adult specimens were not obtained. The instar stage analysis using the relationship between body length and head breadth revealed that all larvae of Chironomus sp. collected from Off Nushiri belonged to the third and fourth instars. Both larval body length and head breadth of Chironomus sp. (Table 3) are greater than those of Chironomus plumosus from Lake Yunoko (TAKEYA, 1958), which was later regarded by SASA (1984) to be a misidentification of $C$. nipponensis. All animals listed above were shown to be not

Table 2. Comparison of cocoons between Tubifex sp. and Limnodrilus hoffmeisteri collected from Off Nushiri, Lake Oze-numa in 23 July 1986.

\begin{tabular}{ccccccc}
\hline & $\begin{array}{c}\text { No. of cocoons } \\
\text { examined }\end{array}$ & Shape & Surface & $\begin{array}{c}\text { Length } \\
(\mathrm{mm})\end{array}$ & $\begin{array}{c}\text { Width } \\
(\mathrm{mm})\end{array}$ & $\begin{array}{c}\text { No. of embryos } \\
\text { contained }\end{array}$ \\
\hline Tubifex sp. & 15 & $\begin{array}{c}\text { spindle or } \\
\text { pear-shaped } \\
\text { cigar-shaped }\end{array}$ & naked & $1.2-1.7$ & $0.9-1.1$ & $2-7$ \\
$\begin{array}{c}\text { Limnodrilus } \\
\text { hoffmeisteri }\end{array}$ & 6 & $\begin{array}{c}\text { covered with } \\
\text { mud }\end{array}$ & $2.5-3.8$ & $1.2-1.6$ & $6-13$ \\
\hline
\end{tabular}


Table 3. Body length and head breadth of Chironomus sp. collected from Off Nushiri, Lake Oze-numa. Specimens collected at each month are combined.

\begin{tabular}{cccc}
\hline $\begin{array}{c}\text { Instar } \\
\text { stage }\end{array}$ & $\mathrm{N}$ & $\begin{array}{c}\text { Body length } \\
\text { (Range in mm) }\end{array}$ & $\begin{array}{c}\text { Head breadth } \\
\text { (Mean } \pm \text { SD in mm) }\end{array}$ \\
\hline III & 34 & $4.6-9.0$ & $0.370 \pm 0.016$ \\
IV & 115 & $8.4-23.8$ & $0.694 \pm 0.044$ \\
\hline
\end{tabular}

carnivorous predators but deposit and/or algal feeders by microscopic examination of their gut contents. Although Procladius species have been known to be primarily carnivorous (e.g., BAKER and M(Lachlan, 1979 ; Hershey, 1986), Procladius sp. in the present study was rather a deposit feeder because the digestive tract was largely occupied by detritus and diatom cells which had been deposited probably on the bottom after their bloom in upper euphotic zone (Fig. 3).

\section{3-2-2. Monthly changes in macrobenthos}

Total number: The monthly total number of macrobenthos at Off Nushiri ranged from $1,698 \mathrm{~m}^{-2}$ in June to $2,924 \mathrm{~m}^{-2}$ in July ; those at Lake Center from $326 \mathrm{~m}^{-2}$ in May to $658 \mathrm{~m}^{-2}$ in June and September (Fig. 4A). The average value of the monthly total number was about five times higher at Off Nushiri $\left(2,356 \mathrm{~m}^{-2}\right)$ than at Lake Center $\left(481 \mathrm{~m}^{-2}\right)$.

Biomass : The monthly total wet weight was from $2.6 \mathrm{~g} \mathrm{~m}^{-2}$ in September to $8.1 \mathrm{~g} \mathrm{~m}^{-2}$ in May at Off Nushiri ; from $0.4 \mathrm{~g} \mathrm{~m}^{-2}$ in August to $1.5 \mathrm{~g} \mathrm{~m}^{-2}$ in May at Lake Center (Fig. 4B). The average monthly total wet weight at Off Nushiri $\left(4.6 \mathrm{~g} \mathrm{~m}^{-2}\right)$ was about seven times larger than that of Lake
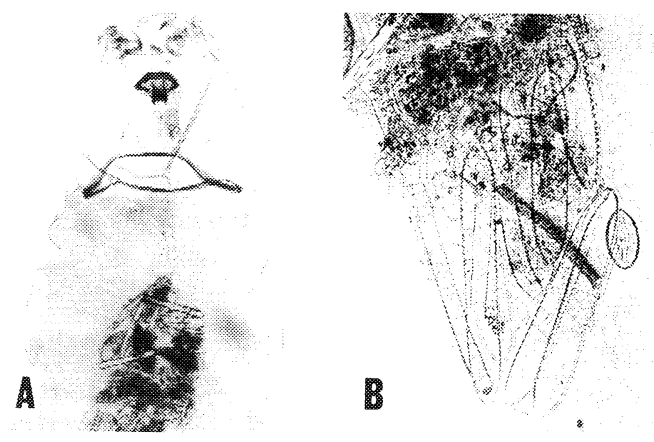

Fig. 3 Anterior part (A) and the gut contents (B) of Procladius sp. from Off Nushiri, Lake Oze numa. Detritus and a number of diatiom shells in different types are seen in the gut.
Center $\left(0.7 \mathrm{~g} \mathrm{~m}^{-2}\right)$. The biomass in both sites clearly decreased from May to September.

Species diversity and faunal composition : Off Nushiri. Species diversity index fluctuated little, being 1.53 bit on the average. The faunal compositions were also relatively constant during the study period. The sum of the two tubificid oligochaetes. Tubifex sp. and Limnodrilus hoffmeisteri, accounted for $79-92 \%$ (average $83 \%$ ) of total number, and 29 $48 \%$ (average $36 \%$ ) of total weight (Fig. 5). The two species showed similar proportions. Chironomus sp. mostly accounted for the rest at Off Nushiri. Another chironomid, Procladius sp., was found in all months, but it formed less than $4.5 \%$ and $2.4 \%$ of total number and weight, respectively (Fig. 5).

Lake Center. Species diversity index fluctuated between 0.10 bit in September and 0.77 bit in May. The average value $(0.42$ bit $)$ was about four times lower than that of Off Nushiri. The faunal composition also varied considerably during the study period (Fig. 5). Tubifex sp. dominated in all months, forming $77.2-98.0 \%$ (average $92.3 \%$ ) in number and 20.3 to nearly $100 \%$ (average $69.0 \%$ ) in weight of total animals. Another tubificid. Limnodrilus hoffmeisteri, was collected only in June and August with low proportions. Chironomus sp. accounted for $22.7 \%$ in number and $79.7 \%$ in weight of total animals in May, then its proportion rapidly decreased.

\section{3-2-3. Monthly changes in some dominant species}

Tubifex sp. : At Off Nushiri, the density fluctuated between $817 \mathrm{~m}^{-2}$ in August and $1,553 \mathrm{~m}^{-2}$ in July (average $1,112 \mathrm{~m}^{-2}$ ) ; at Lake Center, $252 \mathrm{~m}^{-2}$ in May and $648 \mathrm{~m}^{-2}$ in September (average $442 \mathrm{~m}^{-2}$ ) (Fig. 6A) .

Always in both sites, Tubifex sp. population had mature large worms, though their proportion was smaller than those of small to median sized immature worms (Fig. 6B). Cocoons were also collected in every month at both sites. The continuous occurrence of mature worms and 

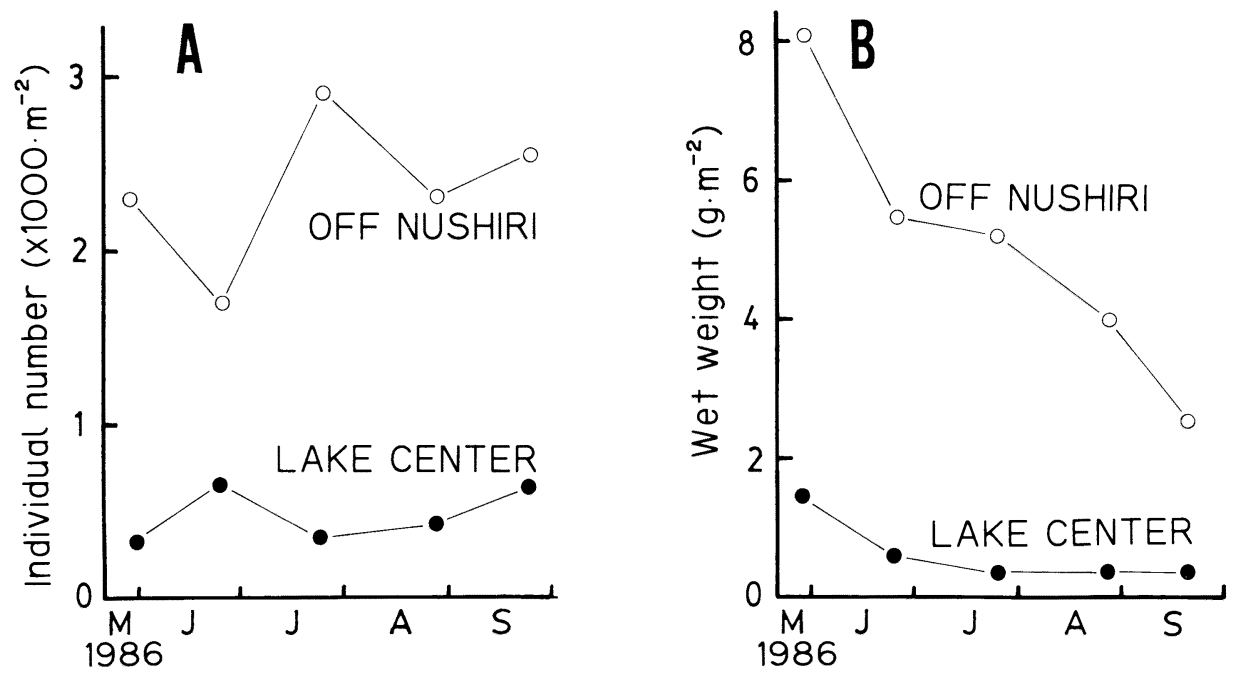

Fig. 4 Monthly changes in total number (A) and total wet weight (B) of macrobenthos at two study. sites in Lake Oze numa.

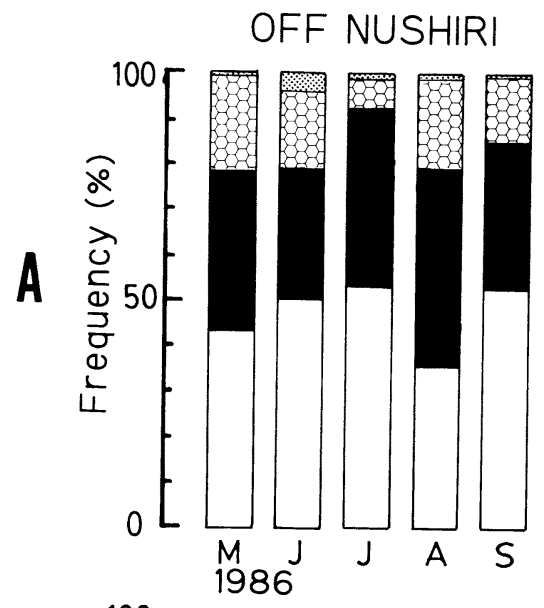

LAKE CENTER

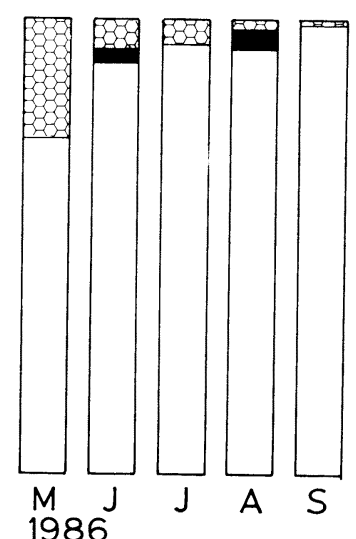

$\square$ Tubifex sp.

Limnodrilus
hoffmeisteri

Ba영 Chironomus sp.

2. Procladius sp.

Others
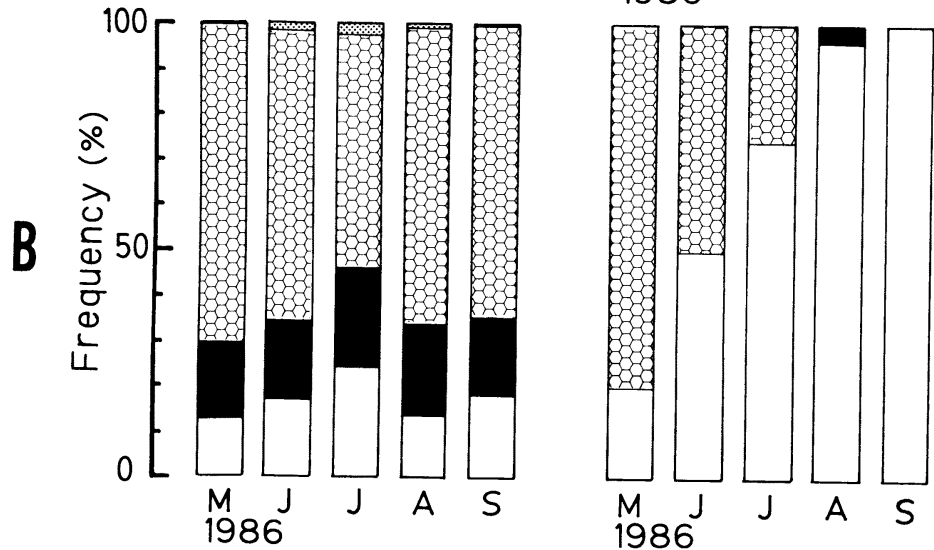

Fig. 5 Monthly changes in relative abundance in number (A) and wet weight (B) of macrobenthos at two study sites in Lake Oze-numa. 

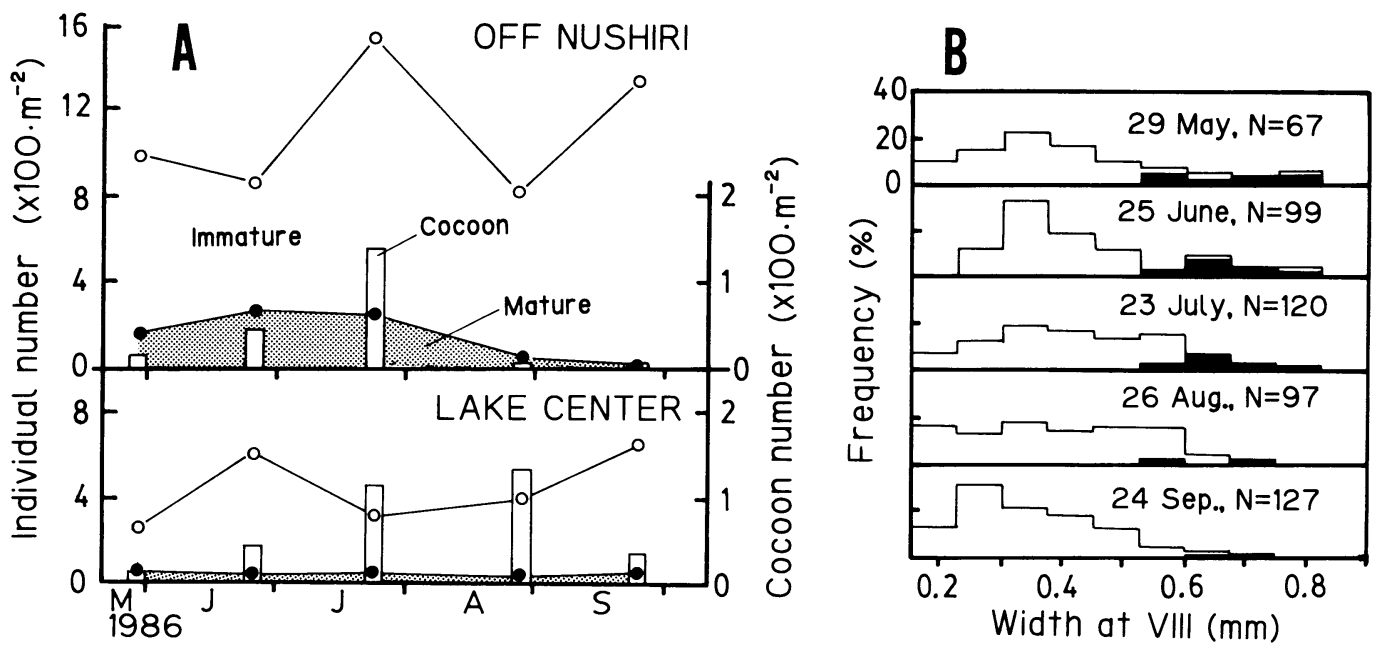

Fig. 6 Tubifex sp. A, monthly changes in densities of the worms and its cocoons. B, frequency distrubution of the width at eighth segment of the worms collected from Off Nushiri. Shaded and soid parts indicate mature individuals.
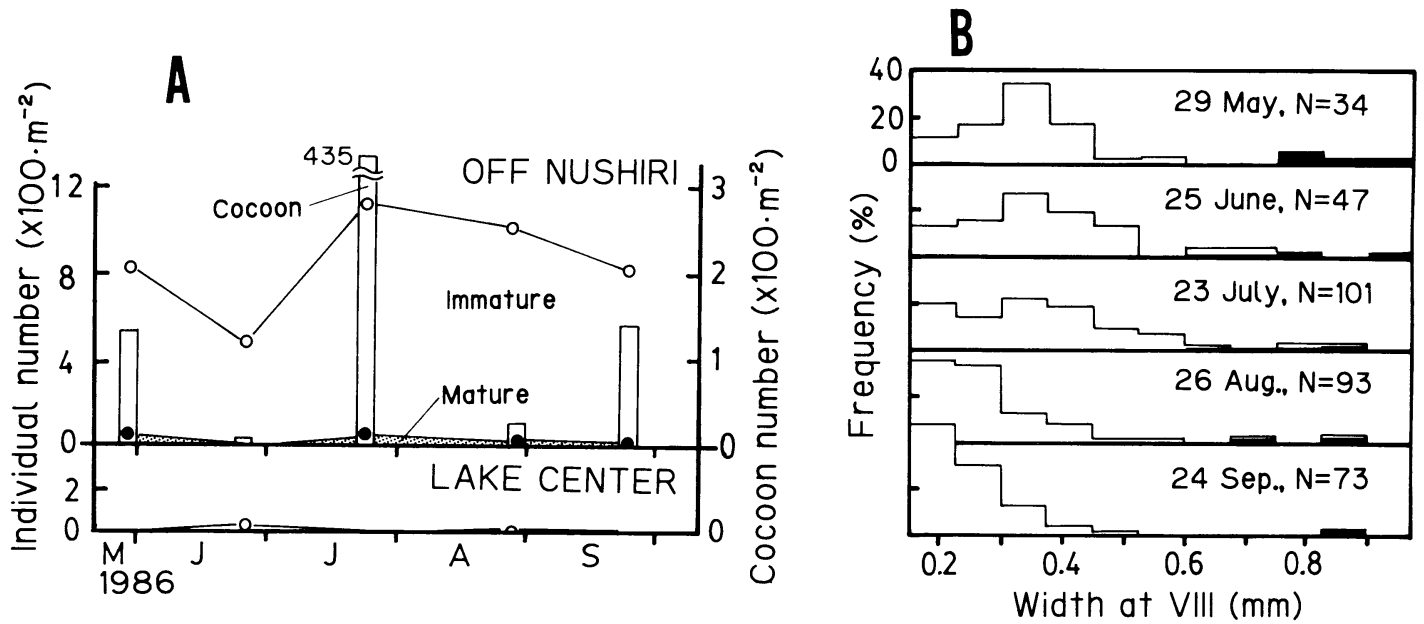

Fig. 7 Limnodrilus hoffmeisteri. A, monthly changes in densities of the worms and its cocoons. B, frequency distribution of the width at eighth segment of the worms collected from Off Nushiri. Shaded and solid parts indicate mature individuals.

cocoons suggests that breeding went on throughout the study period.

Limnodrilus hoffmeisteri: At Off Nushiri, the density was lowest in June $\left(489 \mathrm{~m}^{-2}\right)$ and highest in July $\left(1,138 \mathrm{~m}^{-2}\right.$ ) (Fig. 7A) with the average density of $856 \mathrm{~m}^{-2}$. The maximum number of cocoons was collected in July (Fig. 7A). Small worms markedly predominated both in August and September (Fig. 7B). These small worms were similar in size to the worms about to hatch out. $L$. hoffmeisteri probably bred at Off Nushiri throughout the period under study. At Lake Center, this species was less than $18 \mathrm{~m}^{-2}$ in number. and the cocoons were never found.

Chironomus sp. : At Off Nushiri, the density fluctuated between $187 \mathrm{~m}^{-2}$ in July and $474 \mathrm{~m}^{-2}$ in May (average $351 \mathrm{~m}^{-2}$ ) ; it suddenly increased in August after the successive decrease from May to July (Fig. 8A). On the other hand, at Lake Center the density was less than $75 \mathrm{~m}^{-2}$ (average $31 \mathrm{~m}^{-2}$ ) 

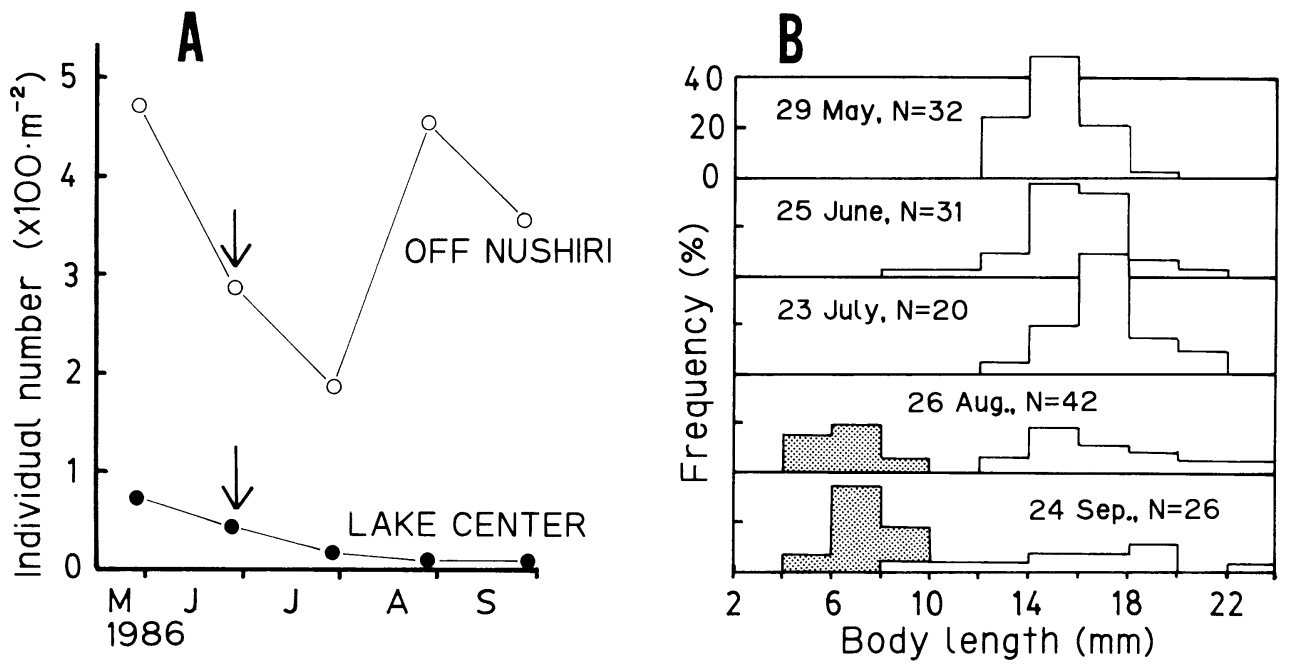

Fig. 8 Chironomus sp. A, monthly changes in densities of the larvae; arrows indicate pupal appearance. B, frequency distribution of the body length of the larvae collected from Off Nushiri; shaded and open parts indicate third and fourth instars, respectively.

and did not fluctuate sharply during the study period.

Populations of Chironomus sp. at Off Nushiri consisted of only fourth instars in the first three months, but both third and fourth instars were involved after August (Fig. 8B). In addition, a few pupae were collected in June at both study sites

(Fig. 8A). These suggest that a part of this species emerged in June, though most fourth instars remained without pupating in this month.

\section{Discussion}

In the present study, eight taxa of zoobenthos including meiofauna were recorded from the profundal zone in Lake Oze-numa. The fauna is much poorer than that of the littoral zone of the lake. For example, about twenty species of zoobenthos including phytal forms were recorded by Ki'RITA et al. (1975), and more than 40 taxa were recorded from littoral regions of Lake Oze-numa (OHTAka et al., 1987). The faunal composition in the profundal zone of Lake Oze-numa is also different from that in pools in adjacent Ozegahara moor where chironomids dominated and oligochaetes were rarely found (Kurasawa et al., 1982).

Differences in composition and abundance of zoobenthos between the two study sites are summarized as follows : 1) The number of taxa was more numerous at Off Nushiri, i.e., crustacean meiobenthos (ostracods and harpacticoids), Procladius sp., and cocoons of Limnodrilus hoffmeisteri were not collected at Lake Center. 2) Species diversity was higher at Off Nushiri. 3) Both density and biomass were higher at Off Nushiri. Mean total values of collected animals were about five times in number and about seven times in wet weight higher at Off Nushiri than at Lake Center. These differences probably reflect the oxygen conditions. A considerable decline of oxygen concentrations in summer has been repeatedly observed in the bottom layers near Lake Center (SAJu) and SAkAguchi, 1954 ; KurITA et al., 1974 ; UjIIYE et al., 1983).

According to KıriTA et al. (1974), the oxygen concentration near Lake Center in summer rapidly declined at 8-9 $\mathrm{m}$ depth and became anoxic at the bottom. At Lake Center in the present study, therefore, the bottom water in summer (8.6-9.1 m deep) was supposed to be poor-oxic. There was, however, enough oxygen dissolved in $6 \mathrm{~m}$ deep water in summer (7.1-5.8 $\left.\mathrm{mg}^{-1}\right)$, so one can expect enough oxygen concentration even in the summer bottom water at Off Nushiri (6.5-7.1 $\mathrm{m}$ deep) which are not much deeper than $6 \mathrm{~m}$. Different mud colors of the two sites are not inconsistent with this view. Productivity of many zoobenthos is said to be influenced by temperatures and organic content of sediments (e.g., P(DDUminat, 1980). In the 
present study, however, mud temperatures were not considerably different between two sites (Table 1), and according to YAJIMA (1973), loss on ignition of sediments is hardly different between near Off Nushiri and near Lake Center (21.4 and 21.9\%. respectively).

The life cycle of Limnodrilus hoffmeisteri is known to have great plasticity depending on local conditions (KeNiner, 1966 ; PondunNaYA, 1980). At Off Nushiri, the population dynamics of Limnodrilus hoffmeisteri resembled that of Tubifex sp. : In both species, mature worms and cocoons were constantly present, and no clear breeding peak was found during the study period (Figs. 6, 7). P(ID) BNaYa (1980) also observed that reproduction of Tubifex tubifex and Limnodrilus hoffmeisteri lasted for a long period of time without interruption.

\section{Acknowledgements}

We express our deep appreciation to Prof. J. Greex (Queen Mary College, London, England) and Dr. H. KATAKLkA (Hokkaido Univ.) for their critical reading of the manuscript. Our sincere thanks go to Dr. A. Surawa (Gunma Univ.) and Mr. Y. NAKAJIMA (Gunma Inst. Public Health) for providing unpublished data. Gratitude is due to Ass. Prof. H. FlkihARA (Niigata Univ.) for identification of chironomids. We are also greatly indebted to the staffs of Oze-numa Visitor Center (Agency for Environment), Numata Forestry Office (Oze Forestry Company), and Chôzô-goya lodge, for giving us facilities for the survey.

\section{摘 要}

\section{尾瀬沼深底部における底生動物の構成と現存量}

本州中部の山間湖である尾瀬沼に扔いて底生動物群 集の構成と現存量を調べた。深底部に水深の異なる 2 地点を設け，1986年 5 月から 9 月まで月 1 回の頻度 で継続調査を行なった。期間中出現した 8 分類群の底 生動物のうち, 両地点とも貧毛類 2 種 (Tubifex sp., Limnodrilus hoffmeisteri) とコスリカ 1 種 (Chironomus sp.) が大型動物の $95.5 \%$ 以上 (個体数比) を占め ていた。湖心（水深 $8.8 \mathrm{~m}$ ) の底生動物はそれより約 $2 \mathrm{~m}$ 浅い沼尻沖と比べ出現種数が少なく, また種多様 度, 密度, 現存量ともに低かった。湖底の溶存酸素量 がこの 2 地点間の違いに打いて重要な要因であると思 われる。

沼尻沖の Tubifex sp. と Limnodrilus hoffmeisteri は, 各月とも多数の幼若個体と小数の成熟個体とで構
成され，さらに卵のうも每月見られたことから期間中 低い割合で継続的に産卵を続けていると推測された。 同地点のChironomus sp. は6月に羽化がみられた が，観察期間を通して蛹化せずに終命幼虫りまま上よ゙ まる個体も多数見的机。

\section{References}

Aizaki, M., Otsuki, A., Fuklimmin, T., Kawai, T., Hosomi, M. and K. MuraokA (1981) : Application of modified Carlson's trophic state index to Japanese lakes and its relationships to other parameters related to trophic state. Res. Rep. Natl. Inst. Environ. Stud., No. 23: 13-31 (in Japanese with English summary).

Arkinpola, N. R. (1983): The structure of cocoons in Limnodrilus hoffmeisteri and Potamothrix moldaviensis (Tubificidae, Oligochaeta). Zool. Zh., 62 : 1734-1736 (in Russian with English summary).

Baker, A. S. and A. J. MCLACHLAN (1979) : Food preferences of Tanypodinae larvae (Diptera : Chironomidae). Hydrobiologia, 62 : 283-288.

Goni, N., Kurita, H. and H. Minentera (1980) : Zoological investigation in lake Oze numa, with relation to eutrophication (personal translation). Ann. Rep. Gunma Inst. Public Health, No. 12 : 147-154 (in Japanese).

HARA, H. (1982) : Preface. In : HARA, H. et al. (eds.), Ozegahara : Scientific Researches of the Highmoor in Central Japan. Japan Society of Promotion of Science, Tokyo.

Hershey, A. E. (1986) : Selective predation by Procladius in an arctic Alaskan lake. Can. J. Fish. Aquat. Sci., 43 : 2523-2528.

Horie, S. (1962) : Morphometric features and the classification of all the lakes in Japan. Mem. Coll. Sci. Univ. Kyoto (B), 29 : 191 262.

Kaburaki, T. (1933) : Notes on the fauna of the Oze district, p.70-94. In : Ministry of Education (ed.), Research Report of a Natural Monument of Japan, Oze District. Tôkô-shoin. Tokyo (in Japanese).

KenNedY, C. R. (1966) : The life history of Limnodrilus hoffmeisteri Clap. (Oligochaeta. Tubificidae) and its adaptive significance. Oikos, 17 : 158-168.

Kurasawa, H., Hayashi, H., Okino, T., Watanabe, Y., Ogawa, M., Morita, T., Isobe, Y. Fukuhara, H. and A. Ohtaka (1982) : Ecological studies on zooplankton and zoobenthos in the pools of the Ozegahara moor, p.277 
-298. In : HARA, H. et al. (eds.), Ozegahara : Scientific Researches of the Highmoor in Central Japan. Japan Society of Promotion of Science, Tokyo.

Kurita, H., Minemura, H. and Y. Miyailara (1974) : Limnological investigation of lake Oze-numa. I. The quality of the lake water, plankton and zoobenthos. Bull. Gunma Biol. Edu. Soc. (Gunma Seibutsu), $23: 15-19$ (in Japanese).

Kurita, H., Minfmura, H. and Y. Miyahara (1975) : Limnological investigation of Lake Oze-numa. II. The quality of the bottom deposit and biotic community (aquatic plant and coastal animals). Bull. Gunma Biol. Edu. Soc. (Gunma Seibutsu), 24:14-18 (in Japanese).

Kurita, H. and H. Minemura (1981) : Limnological investigation of Lake Oze-numa. 4. Animal community in aquatic macrophyte zone (1). Bull. Gunma Biol. Edu. Soc. (Gunma Seibutsu), 30 : 13-18 (in Japanese)

MrYaDI, D. (1936) : Lakes in Nikko district and their biota (personal translation), p.534-576. In : Tôshôgû (ed.), Plants and Animals in Nikko District. Yôkendô, Tokyo (in Japanese).

OHTAKA, A. (1985) : Taxonomical revision of three Japanese Limnodrilus species (Oligochaeta, Tubificidae). Proc. Jap. Soc. syst. Zool., No. $30: 18-35$.

Ohtaka, A., Kuranish, R. B. and A. Ujhy: (1987) : A list of benthic invertebrates in Lake Oze-numa, central Japan. Ann. Rep. Gunma Inst. Public Health, No. 19: 114-120 (in Japanese with English summary).

Pondubnaya, T. L. (1980) : Life cycles of mass species of Tubificidae (Oligochaeta), p.175-184. In : Brinkhurst, R. O. and D. G. CoOK (eds.), Aquatic Oligochaete Biology. Plenum, New York.

SASA, M. (1978) : A comparative study of adults and immature stages of nine Japanese species of the genus Chironomus (Diptera, Chironomidae). Res. Rep. Natl. Inst. Environ. Stud. No. .3: 1-63.
SASA, M. (1984) : Studies on chironomid midges in lakes of the Nikko National Park. Part II. Taxonomical and morphological studies on the chironomid species collected from lakes in the Nikko National Park. Res. Rep. Natl. Inst. Environ. stud., No. 70 : 18-215.

Saljo, Y. and Y. Sakaguchi (1954) : Physicochemical characters of Lake Ozenuma and Konuma (Inlandwater in Oze District V), p.128 -133. In : Ozegahara 1954. Tokyo (in Japanese with English summary).

TAKEYA, T. (1958) : Developmental change of labial plate in Chironomus plumosus (Tendipedidae) and its age and length estimation. Bull. Freshwat. Fish. Res. Lab., 8:7-14 (in Japanese with English summary).

Ujilye, A., Yajima, K., Tajima, A., Kaneko, M., Nagia, A., Seki, S., Hara, Y. and K. Karino (1983) : Limnological study in Lake Jiemon-ike. Ann. Rep. Gunma Inst. Public Health, No. 15 : 141 -152 (in Japanese).

YAJLMA, K. (1973) : Eutrophication and water quality in Lake Oze-numa. J. Water and waste (Yosui to Haisui), 15:1421-1425 (in Japanese).

(著者：大高明史，玉村高等学校，干 370-11 群馬県 佐波郡玉村町; 氏家淳雄, 群馬県衛生公害研究所, $\bar{\top}$ 371 群馬県前橋市岩神町 2 丁目一現住所, フィリピン 厚生省食品薬品局; 馬渡峻輔, 北海道大学理学部動物 学教公, $=060$ 札幌市北区北 10 条西 8 丁目 ; Akifumi OHTAKA, Tamamura Senior Highschool, Tamamura-machi, Sawa, Gunma 370-11 ; Atsuo UjIIYE, Gunma Institute of Public Health, Maebashi, Gunma 371 - present address, Bureau of Food and Drugs, Doh Compound Alabang, Muntinglupa, Metro Manila, Philippines ; Shunsuke F. MAWATARI, Zoological Institute, Faculty of Science, Hokkaido University, Sapporo 060)

$$
\begin{aligned}
& \text { Received : } 25 \text { September } 1987 \\
& \text { Accepted : } 14 \text { January } 1988
\end{aligned}
$$

